\title{
Vertebral B-cell lymphoma mimicking a Pott's disease in a man aged 63 years coming back from Tunisia
}

\author{
C Pouderoux ${ }_{1}^{1}$ C Peyron, ${ }^{2}$ C Chidiac, ${ }^{1,3,4}$ T Ferry, $^{1,3,4}$ on behalf of the Lyon BJ Study \\ Group
}

${ }^{1}$ Service de Maladies Infectieuses et Tropicales, Hôpital de la Croix-Rousse, Hospices Civils de Lyon, Lyon, France

${ }^{2}$ Service de Radiologie, Hôpital de la Croix-Rousse, Hospices Civils de Lyon, Lyon, France ${ }^{3}$ Université Claude Bernard Lyon 1, Lyon, France ${ }^{4}$ Centre International de Recherche en Infectiologie (CIRI), Inserm U1111, CNRS UMR5308, ENS de Lyon, UCBL1, Lyon, France

Correspondence to Dr T Ferry,

tristan.ferry@univ-lyon1.fr

Accepted 9 February 2017
CrossMark

To cite: Pouderoux $C$ Peyron C, Chidiac C, et al. BMJ Case Rep Published online: [please include Day Month Year] doi:10.1136/ bcr-2017-219548

\section{DESCRIPTION}

We report the case of a man aged 63 years, a native from Tunisia, whose medical history was marked by diabetes treated with insulin (complicated with inferior limbs polyneuropathy), an ischaemic heart disease, a peripheral arterial disease and a smoking-related chronic obstructive pulmonary disease. His mother might have had pulmonary tuberculosis. He was retired since 2 years and shared his life between Tunisia and France. He had mechanical back pain since several years, but since 3 months, his back pain awakened him at night and was accompanied with loss of weight and anorexia. There was no fever or night sweats. In Tunisia, he underwent a CT scan showing a retroperitoneal mass infiltrating the left psoas and the left renal artery close to the aorta with the erosion of the L2 cortical and spondylitis (figure 1A, B). There was also regional necrotic lymphadenopathy. The patient decided to return to France and was hospitalised in our infectious disease unit. Clinical examination found no pain at the percussion of lumbar vertebrae, no neurological deficit and cardiopulmonary auscultation was normal. Biological investigations showed an inflammatory syndrome, no cytopenia, normal renal function and normal function tests. The blood culture were sterile, the HIV serology was negative, as were Coxiella, Bartonnella and Rickettsia serologies. The interferon- $\gamma$ release assay was negative. A spinal MRI was performed revealing signal abnormalities of L2, without any lesion of the spinal disc, evocating spondylitis, associated with a necrotic mass of left psoas evocating an abscess (figure 1C-F). Finally, the patient underwent radioguided biopsy of the left psoas mass. The samples stayed sterile in conventional media; universal PCR and mycobacterial cultures were negative. The histological analyses revealed a lymphocytic infiltrate constituted with medium-sized cells showing nuclear anomalies and expressing CD20, in favour of B-cell lymphoma. The patient was transferred to haematology to undergo polychemotherapy.

Pott's disease is the most frequent manifestation of extranodal tuberculosis. It often involves two contiguous vertebral bodies of the thoracic or lumbar segments or can have multilevel involvement. The intervertebral disk is usually preserved until the advanced stage. In the earlier stages, spondylitis can be seen. It can be associated with paraspinal infiltration or masses with calcifications. ${ }^{1}$ Lymphoma, mostly non-Hodgkin, can rarely involve bones. It is characterised by the destruction of the cortical bone with a moth-eaten pattern and

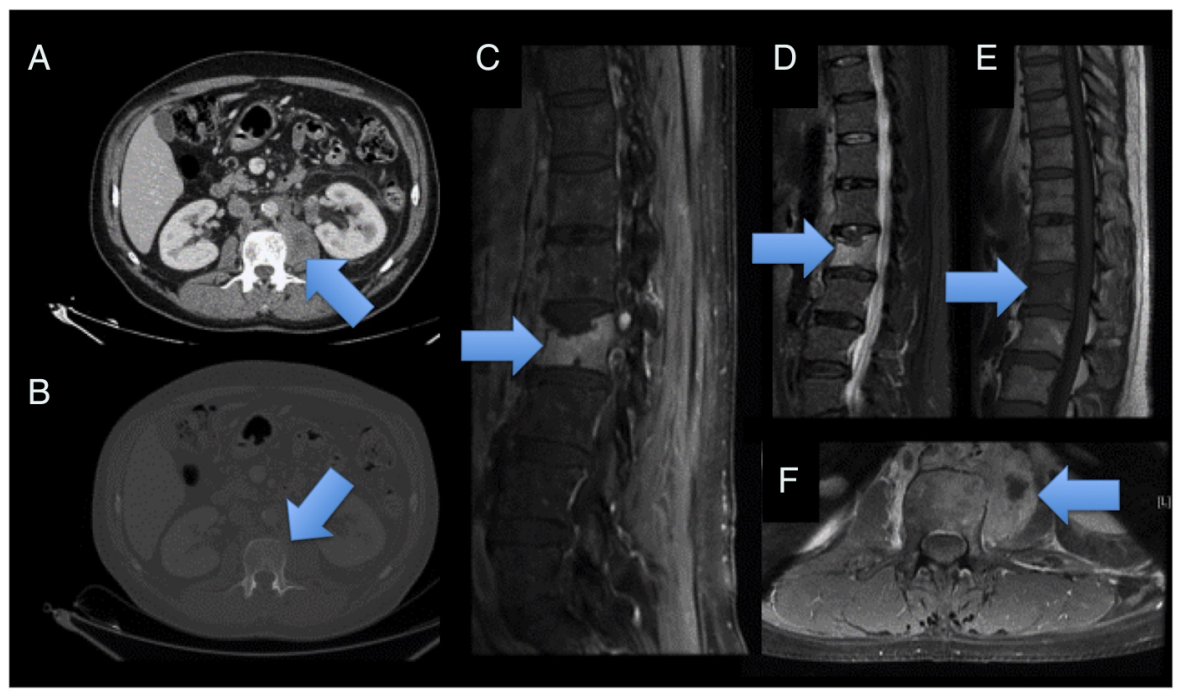

Figure 1 CT scan showing left psoas mass, infiltrating the left renal artery and eroding the anterosuperior plate of L2 vertebrae (arrows, A and B); MRI showing spondylitis aspect of $L 2$ vertebrae which is enhanced by gadolinium in T1 image with fat saturation and erosion of superior plate (arrow, C), high signal of L2 vertebrae in STIR (arrow, D), L2 vertebrae in low signal in T1-weighted sequence (arrow, E) and abscess of left psoas visible in this image injected, T1 weighted with fat saturation (arrow, F). 
is associated in half of the cases with soft tissue masses. Regional lymph nodes can also be seen. In MRI, the signal anomalies can vary. ${ }^{2}$ In our case, the infiltration of the left renal artery was unusual and could have put us on the way of lymphoma. ${ }^{2}$ B-cell lymphoma can mimic Pott's disease and the pathology is essential for the diagnosis.

\section{Learning points}

- Imaging of lymphoma is very polymorphous, especially in the case of bone involvement.

- B-cell lymphoma can mimic Pott's disease with loss of weight and MRI showing spondylitis and psoas abscess.

- The pathology is essential in patients with suspicion of Pott's disease, to exclude B-cell lymphoma.

Acknowledgements Lyon Bone and Joint Infection Study Group: Coordinator: Tristan Ferry; Infectious Diseases Specialists - Tristan Ferry, Florent Valour, Thomas Perpoint, André Boibieux, François Biron, Patrick Miailhes, Florence Ader, Agathe Becker, Sandrine Roux, Claire Filit, Fatiha Daoud, Johanna Lippman, Evelyne Braun, Christian Chidiac, Yves Gillet, Laure Hees; Surgeons - Sébastien Lustig, Elvire
Servien, Yannick Herry, Romain Gaillard, Antoine Schneider, Michel-Henry Fessy, Anthony Viste, Philippe Chaudier, Romain Desmarchelier, Tanguy Mouton, Cyril Courtin, Sébastien Martres, Franck Trouillet, Cédric Barrey, Francesco Signorelli, Emmanuel Jouanneau, Timothée Jacquesson, Ali Mojallal, Fabien Boucher, Hristo Shipkov, Mehdi Ismail, Joseph Chateau; Anesthesiologists - Frédéric Aubrun, Isabelle Bobineau, Caroline Macabéo; Microbiologists - Frederic Laurent, François Vandenesch, Jean-Philippe Rasigade, Céline Dupieux; Imaging - Fabien Craighero, Loic Boussel, Jean-Baptiste Pialat; Nuclear Medicine - Isabelle Morelec, Marc Janier, Francesco Giammarile; PK/PD specialists - Michel Tod, Marie-Claude Gagnieu, Sylvain Goutelle; Prevention of infection - Solweig Gerbier-Colomban, Thomas Benet; Clinical Research Assistant - Eugénie Mabrut.

Contributors $C P$, TF and CC participated in patient care. CP performed the MRI. $\mathrm{CP}$ wrote the manuscript. All authors participated in the literature review and improved the manuscript.

Competing interests None declared.

Patient consent Obtained.

Provenance and peer review Not commissioned; externally peer reviewed.

\section{REFERENCES}

1 Rivas-Garcia A, Sarria-Estrada S, Torrents-Odin C, et al. Franquet imaging findings of Pott's disease. Eur Spine J 2013;22(Suppl 4):567-78.

2 Mulligan ME, McRae GA, Murphey MD. Imaging features of primary lymphoma of bone. AJR Am J Roentgenol 1999;173:1691-7.

3 Demircay E, Hornicek FJ, Mankin HJ, et al. Malignant lymphoma of bone: a review of 119 patients. Clin Orthop Relat Res 2013;471:2684-90.

Copyright 2017 BMJ Publishing Group. All rights reserved. For permission to reuse any of this content visit

http://group.bmj.com/group/rights-licensing/permissions.

BMJ Case Report Fellows may re-use this article for personal use and teaching without any further permission.

Become a Fellow of BMJ Case Reports today and you can:

- Submit as many cases as you like

- Enjoy fast sympathetic peer review and rapid publication of accepted articles

- Access all the published articles

- Re-use any of the published material for personal use and teaching without further permission

For information on Institutional Fellowships contact consortiasales@bmjgroup.com

Visit casereports.bmj.com for more articles like this and to become a Fellow 